\title{
Festas ao Arcanjo São Miguel no contexto de Reforma Católica Ultramontana em Porto Alegre na primeira metade do século $X X$
}

Mauro Dillmann Doutorando em História, Universidade do Vale do Rio dos Sinos/RS

\section{Resumo:}

Este artigo pretende analisar os significados das festas religiosas organizadas ao padroeiro pela Irmandade São Miguel e Almas de Porto Alegre, nas primeiras décadas do século $X X$. A partir da consulta aos livros de atas presentes no Arquivo da Irmandade, pode-se traçar um panorama de como as festas foram discutidas, pensadas e organizadas, focalizando mudanças como a preferência em comemorar no recinto sagrado da igreja a sair em procissão e a variação nas decisões de participar ou não de festividades promovidas por outras irmandades. Por fim, percebem-se através das fontes, os indícios que demonstram os motivos pelos quais as festas continuaram sendo importantes para a Irmandade.

Palavras-chave: Irmandade São Miguel e Almas, festa, Porto Alegre.

Abstract:

This article pretends to analyze the meanings of religious festivals organized to the patron saint by the Brotherhood São Miguel e Almas of Porto Alegre, in the first decades of the twentieth century. Behind from the consultation of the minutes books of the Brotherhood presents in the Archive, we can observe a perspective of how the festivals were discussed, designed and organized, focusing on changes in preference as to celebrate in the sacred precinct of the church, in the same pass going thought procession and the variation in decisions on whether to participate in festivals sponsored by others sororities. Finally, we can detect through the sources, the indication of the reasons why the festivals continued to be important for the Brotherhood.

Keywords: Brotherhood São Miguel e Almas, festivals, Porto Alegre. 


\section{Introdução}

A cidade de Porto Alegre nas primeiras décadas do século $X X$, esteve, assim como muitas outras capitais brasileiras, em franco processo de urbanização e modernização. Fundada oficialmente em 1772, às margens do rio Guaíba, e colonizada por açorianos, tornou-se capital em 1773, ano em que foi construída a igreja matriz, sob a invocação de Senhora Madre de Deus, tendo logo duas irmandades fundadas: Santíssimo Sacramento e São Miguel e Almas.

Ao longo do século XIX, a vivência religiosa católica da população calcada em várias irmandades religiosas caracterizou as organizações de procissões festivas a oragos, sendo que na segunda metade deste século muitos embates e negociações com os bispos católicos ocorreram, especialmente com o bispo Dom Sebastião Dias Laranjeira (TAVARES, 2008). A Irmandade São Miguel e Almas manteve seus propósitos, que eram basicamente devotar seu protetor e garantir sepultamento católico aos irmãos, de preferência em cemitério próprio. Com esse ideal, conquistou seu próprio terreno e no início do século $X X$ inaugurou seu cemitério.

Para além das mudanças nas configurações políticas da passagem ImpérioRepública e da separação entre Igreja e Estado, as festas em homenagem ao Arcanjo São Miguel continuaram ocorrendo, no ritual católico romano, aprovadas e pontificadas pelo bispo ${ }^{1}$, seguindo as recomendações oficiais da Igreja que reforçava a sua Reforma Ultramontana ${ }^{2}$. Porém, as mudanças no modo da Irmandade de conceber a festa nas primeiras décadas do século $X X$, foi fruto, em grande medida, desse processo de Reforma da Igreja Católica e do processo de secularização da sociedade ${ }^{3}$.

\footnotetext{
${ }^{1}$ Dom Cláudio José Gonçalves Ponce de Leão (1890-1912) e Dom João Batista Becker (19121946).

${ }^{2}$ A reforma que vigorou da segunda metade do século XIX até meados do século XX foi um movimento católico que previa a uniformização e "romanização" da Igreja que devia seguir as orientações da Santa Sé. A historiografia é vasta, mas limito-me a citar:MICELI, 2009 [1988];; MARIN, 2009; SANTIROCCHI, 2010; AQUINO, 2012. Para o Rio Grande do Sul: ISAIA, 1998; KARSBURG, 2007; TAVARES, 2008; BIASOLI, 2010.

${ }^{3} \mathrm{O}$ historiador Michel Vovelle percebeu que a festa - vista na perspectiva da longa duração não é uma estrutura fixa, mas um continuum de mutações, de transições, de inclusão e afastamento (VOVELLE, 1991). Essas mudanças são reatualizações dos rituais, considerados mais apropriados, mas não menos sagrados (ELIADE, 2010[1959], 76-77), que podem ou não manter a mesma estrutura, incorporar novos elementos ou eliminar outros. A partir de Durkheim, em As formas elementares da vida religiosa, tem-se um marco para a interpretação da relação entre festividade e vida social, de tal modo que esses eventos podem estar relacionados à ideia de que é a própria sociedade que está sendo comemorada e refeita (MENEZES, 2009).
}

URBANA, V.4, n05, dez.2012 - Dossiê: Cidades e Sociabilidades - CIEC/UNICAMP 
É nesse sentido que discutiremos as formas de organizações de festividades religiosas promovidas pela Irmandade São Miguel e Almas da cidade de Porto Alegre, Rio Grande do Sul, e suas modificações, principalmente quando comparadas àquelas do século XIX, mais preocupadas com as exteriorizações da fé e pela participação plena dos irmãos nas comemorações. Veremos que as festas deixaram de ser caracterizadas pela participação efetiva (mas nunca completamente) dos irmãos em procissões - tanto da própria Irmandade quanto daquelas para as quais era convidada - mas não perdendo suas características religiosas e suas manifestações de fé, que ganhavam ou mantinham outras dimensões: missas, cânticos, coro, orquestra, participação do Arcebispo. Se a Irmandade São Miguel e Almas deixava de realizar procissões e não participava com tanto rigor das demais, embora recebesse convites, promovia anualmente suas festas, com tríduos ${ }^{4}$, missas e assistia às novenas e aos atos solenes das outras instituições. É sobre essas mudanças no festejar e nos seus significados que este artigo se detém, problematizando-os a partir da investigação realizada nos livros de atas no Arquivo da Irmandade, em Porto Alegre.

Com base nesta documentação, pode-se acompanhar a concepção que os irmanados tinham da festa, o modo de expressar sua religiosidade, sua ligação com a Igreja Católica e suas tentativas de divulgar a devoção a São Miguel e o cemitério da Irmandade. A análise que buscou compreender a festa e seus significados, neste artigo, é guiada pelo olhar dos escrivães que registraram em suas reuniões de mesa administrativa, ou seja, vindo de dentro da própria instituição, mas num esforço de compreender também o não-dito, o silenciado, porém significativo. Nesse sentido, pretende-se contribuir para o esclarecimento do interesse que a Irmandade conferia às festas e verificar o empenho desta instituição na sua organização e promoção, durante as primeiras décadas do século XX.

\section{Devoção, Romanização e Festa na cidade}

A devoção a São Miguel Arcanjo foi difundida em Portugal nos séculos XII e XIII com a construção de igrejas e capelas sob sua invocação (EVARISTO, 2002, p. 69). Da Idade Média ao século XVIII eram devotadas orações a São Miguel nos momentos de morte ou de proximidade desta e dedicadas diversas missas em intenção às almas pecadoras que se encontravam provisoriamente no purgatório, um local intermediário entre o Paraíso e o Inferno (CAMPOS, 2004, p. 106). Tido como intercessor para a salvação das almas durante o século XVIII, São Miguel era invocado nas orações,

\footnotetext{
${ }^{4} \mathrm{O}$ significado de 'tríduos' será desenvolvido ao longo do texto.

URBANA, V.4, n5, dez.2012 - Dossiê: Cidades e Sociabilidades - CIEC/UNICAMP
} 
tanto com a finalidade de garantir uma vida terrena tranquila, protegida de qualquer investida dos inimigos, quanto um bom encaminhamento da alma no post-mortem, guardando-a diante de sua fragilidade, e vulnerabilidade a que estava exposta devido aos seus pecadores, no mundo dos mortos. Seu culto e devoção expandiram-se no Brasil, ainda que de modo fragmentado em função do processo de colonização, especialmente entre as vilas e cidades que eram fundadas, como foi o caso de Minas Gerais (CAMPOS, 2004, p. 106).

No século XIX, a devoção ao Arcanjo São Miguel, um culto oficial e universal da Igreja Católica, continuou muito importante nas cidades, especialmente para os fieis irmanados, como no caso de Porto Alegre, que comemoravam seu orago com festas caracterizadas por procissões, fogos de artifício, badalares de sinos e bandas de músicas (TAVARES, 2008).

Mas é nos oitocentos que se impunha nas sociedades cristãs ocidentais um catolicismo romanizado, ou em outras palavras, a reforma católica ultramontana, que passou a regular as práticas religiosas católicas de modo a atingir uma expressão religiosa mais universal, oficial, segundo o modelo romano. Desse modo, a Igreja não mediu esforços para formar um clero mais afinado com a Santa Sé na tentativa de modificar alguns comportamentos dos cristãos nas expressões de fé, como por exemplo, nas festas, geralmente exteriorizadas e vivenciadas de modo peculiar. Tais peculiaridades, de ordem "popular", ou seja, não-oficial, fomentavam críticas por parte da Igreja, considerando-as profanas, deturpadas, mascaradas, hipócritas e irreligiosas (TAVARES, 2008, p. 85).

No Brasil, o controle eclesiástico sobre as manifestações de devoção dos católicos esteve bem caracterizado pelas relações entre os bispos e as irmandades, reforçado a partir da separação entre Estado e Igreja em 1890. No caso da Irmandade São Miguel e Almas de Porto Alegre, sempre houve uma afinação entre o discurso da Igreja e as práticas dos irmãos, visto que a Irmandade mantinha altar lateral na igreja matriz e era formada, fundamentalmente, por um grupo social abastado do ponto de vista econômico e favorável ao catolicismo ultramontano. Mesmo assim, com a intensificação da presença oficial da Igreja na vivência cristã dos sul-riograndenses (ISAIA, 1998: 47) principalmente no Arcebispado de D. João Becker (1912-1946), as festas do Arcanjo São Miguel sofreram algumas transformações.

Até o final do século XIX festa era praticamente sinônimo de procissão. Em Porto Alegre, a Irmandade São Miguel e Almas realizava suas procissões anuais no mês de setembro. Ao combinar a realização de sua festa "com todo o esplendor", em URBANA, V.4, no5, dez.2012 - Dossiê: Cidades e Sociabilidades - CIEC/UNICAMP 
1894, por exemplo, os confrades determinaram fazer "a imagem sair em procissão precedida das imagens pertencentes a irmandade" ${ }^{\prime 5}$. Tal festa ocorria com o apoio e participação do bispo e de membros do clero da cidade, bem de acordo com o espírito de ordem e bênçãos cristãs do catolicismo ultramontano.

Posteriormente, porém, a realização de procissões deixa de ocorrer pelas ruas da cidade. Aos poucos a Irmandade deixava de realizar suas festas com procissões e também deixava de ser assídua frequentadora das festividades de outras irmandades da cidade.

Nas décadas de 1910 e 1920, a Irmandade - que ainda recebia convites para participar de procissões religiosas promovidas por outras confrarias e realizava suas festas com "brilhantismo" - percebeu mudanças nos hábitos tradicionais dos irmãos de acompanhar procissões pelas ruas da cidade. O escrivão Clemente Júlio Borda assim registrou a sua opinião e a determinação da mesa em setembro de 1911:

"Procissão - por mim escrivão foi proposto para que a irmandade não acompanhasse mais as procissões em virtude da dificuldade que se luta para a reunião dos irmãos para esse fim, entrando em discussão foi resolvido que a irmandade só se fará representar com o número de 16 irmãos e mesários, não podendo tomar parte nesse número pessoas estranhas a irmandade ${ }^{\prime 6}$.

Interessante perceber que o escrivão, ao destacar a falta de presença dos irmãos nas procissões religiosas, ressalta com ênfase a "dificuldade que se luta", indicando que já há algum tempo a Irmandade vinha sentindo a carência de efetiva participação dos seus membros nos cortejos para os quais era convidada e se fazia representar. Perdia-se o hábito de acompanhar procissões, mudava-se a concepção de que a festa deveria necessariamente ser acompanhada ou constituída por procissão.

É possível destacar alguns fatores que consideram os motivos pelos quais, aos poucos, os irmãos deixaram de participar das atividades públicas religiosas promovidas por outras instituições. Um deles diz respeito à falta de atitudes de polidez e respeito na forma de tratamento dispensado à Irmandade por parte dos eclesiásticos. Os irmãos da Irmandade São Miguel apreciavam pompas e solenidades,

\footnotetext{
${ }^{5}$ ISMA, Ata, 24 agosto 1894, fl.49.

${ }^{6}$ ISMA, Ata, 12 setembro 1911 , fl. 47.

URBANA, V.4, no5, dez.2012 - Dossiê: Cidades e Sociabilidades - CIEC/UNICAMP
} 
mas também o reconhecimento e a cortesia. No dia 20 de novembro de 1912, a provedoria realizava sua sessão extraordinariamente convocada para resolver sobre a maneira como a Irmandade realizaria a recepção do novo Arcebispo D. João Becker (1912-1946). Isso porque, segundo registro em ata, a comissão encarregada dos festejos ao Arcebispo faltou com a devida cortesia aos representantes da Irmandade. Segundo o registro, "a descortesia foi ostensiva aos demais representantes de outras irmandades". Nessa ocasião, o provedor teria se retirado e, então, reunido com os irmãos em mesa, procurava ouvir a opinião dos mesmos "afim de prestar ao Sr. Arcebispo a homenagem que for resolvida"7 . Percebe-se que a forma de tratamento, o respeito e a cortesia por parte do clero para com os irmãos de São Miguel não estavam à altura do desejado, a ponto dos representantes se retirarem da solenidade de recepção ao Arcebispo Dom João Becker.

Diversos irmãos manifestaram suas opiniões e, então, o provedor propôs que a Irmandade fizesse a festa em homenagem ao Arcebispo "por conta". Para dar as boas vindas ao novo Arcebispo, os confrades resolveram promover um solene Te Deum ${ }^{8}$ entoado por uma orquestra. Apenas um irmão mesário colocou-se contra essa proposta e fez valer sua opinião. Era Manoel Luís Postiga, argumentando que "o nosso compromisso não tem artigo algum que dê o direito de lançar mãos do dinheiro da irmandade para fazer festa". A proposta de Postiga, que seria aceita pelos demais, considerava que a festa deveria "ser feita às espensas da mesa administrativa e mais irmãos que quiserem contribuir para esse fim". Logo, foram nomeadas duas comissões; uma para recepção do Arcebispo, composta por Abelardo Marques, Manoel Dias Campos, Clemente Júlio Borda, e outra para visita ao Palácio Episcopal, composta por Luiz Rocha Farias, Manoel Luiz Postiga, Monoel Dias Campos, João Damasceno Ferreira e Cel. Ernesto Theobaldo Jager ${ }^{9}$. Dessa forma, a Irmandade cumpria cerimonialmente uma função de ato solene - recepção do Arcebispo importante com toda a pompa e distinção ${ }^{10}$.

Outro fator é a consideração de que a procissão religiosa não tinha mais, necessariamente, a intenção de divertir, embora a Igreja Católica já condenasse

\footnotetext{
${ }^{7}$ ISMA, Ata, 20 novembro 1912, fl.57v, 58.

8 Um hino sacro de ação de graça, iniciado com Te Deum Laudamus (A vós, senhor, louvamos). Para uma explicação mais aprofundada e uma breve história do Te Deum: (COUTINHO, s/d).

9 ISMA, Ata, 20 novembro 1912, fl. 57v, 58.

${ }^{10}$ No ano seguinte, 1913, a Irmandade assistiu aos festejos realizados na catedral em ação de graças pela imposição do "sagrado Pálio ao Exmo. Revmo. Senhor Arcebispo metropolitano, Dom João Becker". ISMA, Ata, 11 agosto 1913, fl. 64.

URBANA, V.4, no5, dez.2012 - Dossiê: Cidades e Sociabilidades - CIEC/UNICAMP
} 
desde meados do XIX essa característica de divertimento nesses eventos religiosos. Outras opções de vivência cultural e lazer se apresentavam, como teatros, cinema, carnaval e as festas deixavam de ser momentos exclusivos (e próprios) para tais finalidades (TAVARES: 2008, p. 50). Diante de tantas alternativas que a cidade dispunha e frente ao grande número de comemorações religiosas, os irmãos acabam por selecionar, dar preferências e optar por uma delas, deixando, muitas vezes, a frequência às procissões em segundo plano.

Seguindo as orientações da Igreja Católica, sua defesa da moralidade que previa a santificação das festas e de todos os atos nela praticados, outra hipótese aponta para esse caminho. Os irmãos, pertencentes a uma seletiva parcela bem sucedida da população porto-alegrense - políticos, funcionários públicos, comerciantes, industriais, etc - podiam estar convencidos - como a Igreja estava - de que as procissões ressaltavam o profano em momentos de balbúrdia, de divertimentos, de espetáculos, desnecessários à devoção e incitadores da desordem. Portanto, não participavam efetivamente de festas de suas congêneres bem como não faziam mais festas com procissões pelas ruas da cidade.

Ao realizar um histórico da Irmandade Nossa Senhora do Rosário de Porto Alegre em 1932, o padre José Barea, apontou que a Irmandade São Miguel e Almas "já não convida a ninguém nem aparece em parte alguma", sendo que "suas festas passam quase inteiramente despercebidas" (BAREA, 2004, p. 129).

Evidencia-se então que as possíveis ausências da Irmandade em procissões e festas promovidas por outras instituições religiosas eram movidas pela exigência da Irmandade São Miguel de formas de tratamento cortês, pelas variadas oportunidades de lazer que os irmãos possuíam e pela concepção de que a manifestação de devoção deveria ser mais contida, no sentido proposto pelo catolicismo reformado. Esses fatores podem ser resultado da valorização e do entendimento de que as festas deveriam ser mais privadas ou no âmbito do recinto sagrado, dentro da igreja.

Portanto, ao longo das primeiras décadas do século $X X$, a compreensão de como a festa deveria ser organizada mudou. Se por um lado, não se falava em procissão a São Miguel, em participação de centenas de pessoas, em manifestações populares de devoção como pagamento de promessas e oferendas de velas, flores, etc., se registrava a participação das mulheres no coro, nas rezas e vocalização de ave-marias $^{11}$, no comparecimento de autoridades, no envolvimento do Bispo para

\footnotetext{
${ }^{11}$ ISMA, Ata, 19 setembro 1923, fl. 107v.

URBANA, V.4, n05, dez.2012 - Dossiê: Cidades e Sociabilidades - CIEC/UNICAMP
} 
pontificar a festa"12, no "brilhantismo da festa de São Miguel", a ponto de se lançar em ata "voto de louvor pelos esforços empregados para o brilho da referida festa" ${ }^{13}$.

A modernização pela qual passava a cidade, com a construção de grandes prédios, abertura de ruas e formação de avenidas, não excluía a dinâmica da vida religiosa e não estava na contramão da experiência da fé dos seus sujeitos. As rápidas mudanças políticas e econômicas não foram acompanhadas de mudanças abruptas nos modos de sentir e crer. Ao longo do Império o processo de secularização ${ }^{14}$ vinha sendo processado na sociedade. A separação entre Estado e Igreja, em 1890, acentuou esse processo em termos institucionais, mas não em termos de sentimentos religiosos. Houve gradativa mudança no modo de expressar a devoção, mas os ritos religiosos - entre eles as festas - dos leigos fiéis somados ao calendário católico oficial continuaram ocorrendo ${ }^{15}$.

Cabe verificar, então, como eram organizadas as festas de São Miguel no início do século XX em Porto Alegre e quais eram os seus elementos festivos.

\section{As festas de São Miguel}

As festividades eram momentos importantes para os irmãos de São Miguel, principalmente para a Mesa administrativa que ao longo do período analisado se esforçou em convocar os mesários e demais sócios para o comparecimento às festas. Promoviam-se reuniões específicas para tratar da festa que estava prevista no compromisso e esforçavam-se para que houvesse participação e envolvimento de todos os irmãos. Convites da Irmandade eram enviados a todos os irmãos, às autoridades políticas e eclesiásticas e também publicados nos principais jornais da cidade.

A organização das festas foi feita ora com "toda a pompa", ora "com toda a simplicidade". De modo geral as festividades eram marcadas pela grandeza e

${ }_{12}$ ISMA, Ata, 19 setembro 1918, fl. 54v, Ata, 16 setembro 1919, fl.65.

13 ISMA, Ata, 21 abril 1908, fl. 9.

${ }^{14} \mathrm{O}$ conceito de secularização aqui utilizado conotativamente como "a perda, nas sociedades ocidentalizadas, da posição-chave que a religião institucionalizada ocupava na produção e na reprodução do elo social e na atribuição de sentido. O que, se não implicou o desaparecimento do sagrado, provocou uma maior eufemização das fronteiras entre o religioso e o nãoreligioso". (CATROGA: 2006, 62).

${ }^{15}$ Essa continuidade de festas religiosas entre o Império e a República foi constatada no Rio de Janeiro, no estudo de Martha Abreu sobre as manifestações populares. As festas, apesar de criticadas, foram aceitas e incorporadas à cidade e outras comemorações foram criadas como de Nossa Senhora da Penha, mesmo diante do autoritarismo do novo regime político (ABREU, 1999 , p. 339). As autoridades municipais cariocas do período republicano, continuaram lidando com as licenças para festas religiosas, constantemente requeridas por parte das irmandades (ABREU e VIANA, 2009, p. 262).

URBANA, V.4, n05, dez.2012 - Dossiê: Cidades e Sociabilidades - CIEC/UNICAMP 
distinção, no entanto, em ocasiões específicas como gastos extremos com o cemitério - inaugurado em 1909 e frequentemente em reformas nas primeiras décadas do século XX - ou falecimento de um mesário, a simplicidade deveria contar, ocasião em que eram feitos apenas missas para os mortos e missa de guardião ${ }^{16}$, mas registravase a intenção de "futuramente se fazer melhor"17.

Nesse período, para a Irmandade São Miguel e Almas, as festas não implicavam mais em procissões pelas ruas da cidade. Considerar-se-ia que festa não era mais necessariamente sinônimo de procissão e na organização desta, outros elementos constituíam a homenagem pública ao patrono: missas, cânticos, coro, sermão, foguetes, decoração.

A organização da festa era feita com muito trabalho e dedicação. Era necessário providenciar o sermão, contratar um capelão, distribuir convites, mandar publicar nos jornais, enviar ofício para a polícia, providenciar decoração, organizar comissões de representação na abertura, de recepção dos convidados, agendar com o coro da Catedral, agenciar contrato com orquestras, mandar confeccionar santinhos e brindes, como medalhas do Arcanjo, etc.

Assim como nas comemorações em outras localidades brasileiras, a participação das mulheres era marcante e importante nas celebrações (SOUZA, 2008), todavia não participavam da mesa administrativa. A elas cabia honrosamente aceitar a eleição de juízas de festa, cargo para o qual havia eleições anuais e passava pela prévia aceitação do marido. A juíza eleita podia recusar o cargo, mesmo assim a ela cabia o encargo de pagar o sermão, o trabalho do capelão, a sua contribuição para a festa, que era estabelecido em compromisso ${ }^{18}$.

Um ano após a inauguração do cemitério, ainda com muitas despesas, a Irmandade realizava sua festa às "expensas da mesa para não sobrecarregar essa despesa aos cofres da irmandade", constando de "festa de missa solene na catedral"

16 ISMA - Arquivo da Irmandade São Miguel e Almas de Porto Alegre, Livro de Atas das Sessões, 1916-1933, Ata 21 setembro 1920, fl.73. Para este artigo foram utilizados quatro Livros de Atas, cujos períodos são os seguintes: 1907-1916, 1916-1933, 1933-1937 e 19371952.

${ }_{17}$ ISMA, Ata, 21 setembro 1921, fl. 86.

${ }^{18}$ No entanto, a contribuição da juíza eleita nem sempre se efetivava, talvez por não poder participar por motivos de enfermidade, como ocorreu em 1927 com Marieta de Morais Pacheco. O certo é que a irmã que renunciasse ao cargo de juíza poderia obter sua remissão desde que pagasse o sermão determinado, mas isso nem sempre ocorria. Em 1937 registravase em ata que "casos houve em que muitas das irmãs convidadas para juízas, não pagaram essa taxa atendendo suas condições, correndo tal despesa por conta da irmandade". ISMA, Ata, 19 setembro 1927, fl.132v; ISMA, Ata, 14 maio 1937, fl. 94v.

URBANA, V.4, n05, dez.2012 - Dossiê: Cidades e Sociabilidades - CIEC/UNICAMP 
acompanhada por orquestra e missa na capela do cemitério"19. Note-se o termo "festa de missa", levando a crer que a missa em si, quando em homenagem ao padroeiro, era um motivo e elemento festivo. O patrocínio dos irmãos, e não da Irmandade enquanto instituição, era uma forma de manter as festividades, promovendo uma economia financeira, destinando os recursos da associação ao cemitério, sua principal prioridade naquele momento. Aberta para todos que desejassem contribuir com as despesas que estavam por acontecer, em 1911, a mesa "correu uma lista a fim de angariar as importâncias para festejar o dia do nosso arcanjo"20.

Com o cemitério já consolidado e o compromisso reajustado, em 1912, o provedor propôs a festa com "toda a pompa" e que fosse feita "às expensas dos cofres da irmandade", pois "não havia mais necessidade de sacrificar os seus irmãos de mesa"21.

A Irmandade São Miguel e Almas continuou realizando plenamente esses ritos em Porto Alegre, tornando-os públicos e investindo em pompas, acarretando despesas em nome da publicidade da devoção e das suas práticas fúnebres ${ }^{22}$. Há de se considerar que na promoção de festas nem tudo era despesa, pois eram angariados fundos, distribuídas caixinhas nas missas e recolhidos donativos. O saldo, muitas vezes positivo, era aplicado em outras atividades religiosas promovidas pela Irmandade como missas às almas no dia de finados (DILLMANN, 2012).

A organização festiva ocorria, então, nos moldes do catolicismo romano, geralmente com "missa de guardião", acompanhada de canto e de incenso, ocorrendo no interior da igreja matriz ou na capela existente no cemitério com a presença, muitas vezes, do Arcebispo.

\section{Calendário festivo de Porto Alegre}

O calendário religioso intenso e os constantes convites que chegavam, marcavam uma agenda de compromissos aos irmãos de São Miguel. No ano de 1913, além da sua festividade referente ao dia do Arcanjo, a Irmandade recebeu dois convites. As missas, geralmente aconteciam pela manhã. Não havia como deixar de participar da missa solene Te Deum celebrada às 10 horas do dia 13 de maio em

\footnotetext{
${ }^{19}$ ISMA, Ata, 12 setembro 1910, fl.34.

${ }^{20}$ ISMA, Ata, 12 setembro 1911, fl.46v.

${ }^{21}$ ISMA, Ata, 14 setembro 1912, fl. 55v.

${ }^{22}$ Segundo o antropólogo Marcel Mauss, os ritos religiosos são solenes, públicos, obrigatórios e regulares. Esta observação, bem como uma boa análise da obra de Marcel Mauss: (PEREIRA, 2005).

URBANA, V.4, no5, dez.2012 - Dossiê: Cidades e Sociabilidades - CIEC/UNICAMP
} 
"ação de graças" pelo primeiro aniversário da sagração episcopal de D. João Becker. Em setembro, havia a festa de Nossa Senhora das Dores, sendo a mesma promovida pela Ordem Terceira para sua padroeira realizada com procissão a partir das 17 horas, evento para o qual a Irmandade designou alguns irmãos a participar.

A Irmandade sempre recebeu muitos convites de outras irmandades e instituições religiosas para participar das suas festas e sempre que possível participou com alguns representantes ou comissões nomeadas para tal fim. Na primeira década do século XX, a secretaria da São Miguel recebia ofícios da Irmandade do Santíssimo Sacramento, da Ordem Terceira de Nossa Senhora das Dores, da Santa Casa de Misericórdia, da Arquiconfraria de Nossa Senhora do Rosário, da Irmandade do Divino Espírito Santo, para assistir e comparecer aos atos religiosos e procissões de Nossa Senhora Madre de Deus, procissão de Enterro, procissão do Senhor dos Passos, procissão do Senhor Morto e novena em louvor ao Espírito Santo, respectivamente ${ }^{23}$. Em 1913, diante de vários convites, foi sublinhado em ata que a Irmandade tinha se feito representar em todos esses atos ${ }^{24}$.

Além destes eventos religiosos, a Irmandade se fazia representar nas festas da Semana Santa, para a qual doava anualmente uma quantia de $50 \$ 000$ réis a pedido, sempre, do Cura da Catedral ${ }^{25}$. Havia também a participação na procissão da Irmandade do Divino Espírito Santo e na procissão de Corpus Christi ${ }^{26}$, onde todas as irmandades da cidade participavam. E aquelas festas de outras devoções, que eventualmente, foram registradas, como Santa Teresinha, N. S. da Glória e São Francisco Xavier.

Com os passar dos anos - com o Arcebispado de D. João Becker consolidado a tal ponto de participar este, ativamente, das festividades religiosas e de a Irmandade promover festas, contando com a presença de outras instituições religiosas - a Irmandade São Miguel e Almas se viu na obrigação de comparecer nos momentos festivos de outras irmandades.

O calendário religioso da cidade ainda contava com muitas procissões, com ênfase para as oficiais e tradicionais (como as citadas acima), com controle

\footnotetext{
23 ISMA, para as três primeiras: Ata, 06 maio 1907, fl.3-5; 21 abril 1908, fl.9-10. Para o convite de Nossa Senhora do Rosário, Ata, 22 abril 1913, fl. 61v; e para o convite do Divino Espírito Santo, Ata, 11 agosto 1913, fl. 64.

24 ISMA, Ata, 22 abril 1913, fl. 62.

25 ISMA, Ata, 17 março 1910, fl. 25.

${ }^{26} \mathrm{Em} 1927$ a irmandade recebeu um pedido de auxílio monetário, vindo do Centro da Boa Imprensa, "para as despesas com a ornamentação das ruas por onde terá de passar a procissão de Corpus Christi. A irmandade, no entanto, não atendeu ao pedido, alegando "evitar a continuação de tal pedido". ISMA, Ata, 13 junho 1927, fl. 128,128v.
}

URBANA, V.4, n5, dez.2012 - Dossiê: Cidades e Sociabilidades - CIEC/UNICAMP 
eclesiástico, sem muitas novenas, sem abundância de fogos e sem efervescência de ritos (PEREZ, 2011: 153), mas com as formalidades exigidas pelo culto romano.

Em meados de 1918, pelo irmão Alves da Silva foi proposto à mesa:

"agora reunida revogasse a decisão de igual mesa em sessão de 12 de setembro de 1911 que estabeleceu o comparecimento de nossa irmandade em quaisquer procissões somente no caso de reunido para mais de 16 irmãos mesários, ou então que tomasse a deliberação a comparecer somente as procissões de N. S. Madre de Deus e S.S. Corpo de Deus, com qualquer número de irmãos"27.

Dentro de sete anos, entre 1911 e 1918, a Irmandade mudou sua determinação sobre a presença ou não nas festas religiosas de outras associações. A nova postura da Irmandade em 1918, a de abolir a determinação de que ela somente se faria representar às festas e procissões com número mínimo de 16 irmãos, aponta que dificilmente a Irmandade conseguia reunir tal número de confrades e também para a necessidade e/ou obrigação de retribuir ao prestígio que se tinha nas festas de São Miguel. A partir de 1918, nova postura pautou a Irmandade: "posto a votos foi depois de acalorada discussão abolida a praxe estabelecida, devendo nossa irmandade comparecer a todas as procissões quando convidada"28.

Nomeando comissões, a Irmandade participou das festas para as quais era convidada e tinha a certeza de poder contar com a participação das outras confrarias nas suas promoções festivas. Aqui podemos dizer que as irmandades entravam num esquema de obrigações de prestações recíprocas, que se revestem em forma de dádivas na acepção de Marcel Mauss, onde a regulação é "dar, receber, retribuir"29.

Em 1916, a Irmandade se fez representar em todas as tradicionais festas da cidade, programou a sua festa e ainda esteve na homenagem anual ao Arcebispo pela sua sagração. Trocas de ofícios entre as irmandades para a organização e participação em eventos como esse que mobilizavam os fieis católicos da cidade eram bastante

\footnotetext{
27 ISMA, Ata, 19 junho 1918, fl.50.

${ }^{28}$ ISMA, Ata, 19 junho 1918, fl. 50.

${ }^{29} \mathrm{O}$ antropólogo destacou: "Se coisas são dadas e retribuídas, é porque se dão e se retribuem 'respeitos' - podemos dizer igualmente 'cortesias'. Mas é também porque as pessoas se dão ao dar, e, se as pessoas se dão, é porque se 'devem' - elas e seus bens - aos outros" (MAUSS, $2003[1950])$.

URBANA, V.4, n5, dez.2012 - Dossiê: Cidades e Sociabilidades - CIEC/UNICAMP
} 
comuns. Entre as irmandades São Miguel e Almas e a Imaculada Coração de Maria as trocas e prestações recíprocas de cortesias, geravam correspondências com objetivos de agradecer a "gentileza"30.

A Irmandade estava atenta ao calendário religioso das demais instituições religiosas da cidade. Muitas vezes, ao planejar suas festividades, cuidava para não haver coincidências.

Em 1934, o vice-provedor comunicava que mandaria:

"celebrar missa no dia 29 do corrente por alma dos irmãos falecidos e realizar-se a festa em louvou de nosso padroeiro, no dia 7 de outubro, constando a mesma de missa festiva de guardião, sendo o coro o da catedral, quanto a festa ser nesse dia, era motivado por ter a festa de Santa Teresinha no dia 30 de setembro e achar a provedoria, não convir, fazer a de São Miguel no mesmo dia" ${ }^{31}$.

Celebrado no dia 29 de setembro de cada ano, as festividades nem sempre ocorriam nesse dia, pois às vezes coincidiam com outras festas religiosas ou se privilegiava que a celebração ocorresse aos finais de semana. Nestas ocasiões, transferia-se para o primeiro ou segundo domingo do mês de outubro, ou era antecipada a festa, como ocorreu em 1925: "...celebrada no dia 27, por ser domingo e facilitar o comparecimento em maior número de irmãos e devotos, e que a festa conste de tríduos nos dias 24, 25 e 26 às 18 horas e no dia 29 uma missa em sufrágio às almas dos irmãos"32.

Semelhante situação ocorrera em 1930, quando o provedor registrava "que sendo o dia 29 segunda-feira, propõe que a festa de São Miguel seja realizada no dia 28, domingo, facilitar o comparecimento dos irmãos"33.

Independente do dia da semana, sempre no dia santo de 29 de setembro era celebrado missa às almas falecidas. A comemoração festiva acontecia nos dias 29 em duas condições: se fosse sábado ou domingo, ou, se não coincidisse com qualquer outra atividade religiosa da cidade. Nestes casos ela era antecipada ou adiada. Vale citar como exemplo alguns casos da década de 1920 e 1930.

\footnotetext{
${ }^{30}$ ISMA, Ata, 11 setembro 1916, fl. 7v.

31 ISMA, Ata, 21 setembro 1934, fl. 20.

32 ISMA, Ata, 17 setembro 1925, fl. 120v.

33 ISMA, Ata, 19 setembro 1930, fl. 157.

URBANA, V.4, no5, dez.2012 - Dossiê: Cidades e Sociabilidades - CIEC/UNICAMP
} 
Em 1926, pensando a celebração festiva com a possível pompa e "para que possa ter maior comparecimento de irmãos e devotos, a missa festiva seja celebrada no domingo, 03 de outubro" ${ }^{\prime 34}$. Outras associações, como a Arquiconfraria do Rosário, também transferiam suas festividades em função de São Miguel. Informa-nos D. José Barea que "às vezes a irmandade do Rosário transferia a sua festa para o segundo domingo de outubro, a fim de que no primeiro se pudesse celebrar a festa de São Miguel" (BAREA, 2004, p. 129).

Em 1936, foi registrado que

\begin{abstract}
"devido a ser o dia 29, dia de semana, fosse rezada nesse dia uma missa em intenção das almas dos irmãos falecidos. Tendo sido informado no primeiro domingo do mês de outubro (dia 4) deverá realizar-se na crypta da Catedral a sagração do Bispo de Vacaria, não podendo por esse motivo realizar-se a festa de São Miguel, ficou combinado com o coadjuctor da Catedral, padre Luiz Sartori, fazer-se a mesma no dia 11 do referido mês"35.
\end{abstract}

Raramente, então, a festa ocorria de fato no dia 29, mas em datas combinadas e de acordo com a programação da Arquidiocese ou de suas congêneres. No período analisado, apenas no ano de 1928 a Irmandade deixou, por um motivo assistencial, de realizar a festa ao seu padroeiro. Naquela ocasião o irmão Emílio José Pacheco lembrava que "estando uma parte da população desta capital sofrendo prejuízos e ficando reduzida à miséria com a enchente que se nota em proporções assustadoras, propõe que este ano não se faça a festa de São Miguel"36. A proposta era distribuir "em favor dos flagelados" a quantia de dois contos de réis e deixar de realizar a festa, fato que gerou polêmica e discussão, sendo por muitos considerada "louvável" e por outros uma "demasia". Todavia a proposta foi aprovada, sendo encaminhado o donativo ao jornal Correio do Povo para encarregar-se da distribuição.

\footnotetext{
${ }^{34}$ ISMA, Ata 17 setembro 1926, fl. 125.

35 ISMA, Ata, 21 setembro 1936, fl. 78v. Em 1931, ficou resolvido que a festa de São Miguel fosse "celebrada no dia 27 de setembro, constando de missa solene, e no dia 29 será rezada uma missa em intenção às almas falecidas". ISMA, Ata, 31 agosto 1931, fl. 162v. No ano seguinte, "a mesa resolveu que a festa seja celebrada, com a possível pompa, a 2 de outubro, e no dia 29 de setembro seja rezada a missa em intenção das almas dos nossos irmãos falecidos". ISMA, Ata, 14 setembro 1932, fl. 178. Ou então, como em 1933, "missa de guardião no dia 29 e festa no próximo domingo". ISMA, Ata, 19 setembro 1933, fl. 191.

${ }^{36}$ ISMA, Ata, 17 setembro 1928, fl. 138v.

URBANA, V.4, no5, dez.2012 - Dossiê: Cidades e Sociabilidades - CIEC/UNICAMP
} 
Diante destes contatos com outras irmandades e com o Arcebispo, com aproximações e afastamentos, nota-se que a Irmandade São Miguel e Almas continuou festejando seu orago. Cabe questionar quais as evidências de que a festa continuava a ser um momento importante para a Irmandade, ou seja, os motivos pelos quais a festa ao Arcanjo prosseguia em Porto Alegre.

\section{Novos significados do festejar}

Como vimos, geralmente as celebrações festivas se estendiam por mais de um dia ou em mais de uma ocasião. Diferentes momentos, dias, horários e atos marcavam a festa. Como ela estava bem caracterizada pela utilização do espaço da igreja matriz, que na década de 1920 passava por reformas de reconstrução, os irmãos reforçavam que "para conservar a tradição de nossos antepassados devemos fazer todo possível para que o nosso padroeiro tenha um altar de destaque e admiração" ${ }^{37}$.

A preservação de costumes, um elemento significativo para a Irmandade, estava expresso na praxe de ler - nos dias de festa - os nomes da mesa eleita. 0 vice-provedor, no ano de 1934, dizia "que a irmandade segue a praxe adotada desde o início, de sua fundação, a qual é, no dia da festa de seu padroeiro ser lida pelo pregador ou pelo capelão da irmandade, a relação dos nomes dos novos irmãos eleitos"38. Essa leitura "pública" dos novos mesários, além de tradicional, era um modo de garantir certa "visibilidade" social, gerando status individual e promovendo a Irmandade.

Os três dias de celebrações, geralmente antecedentes da festa de um santo, eram e são chamados de tríduos. São momentos de missas, ladainhas, orações que, aos olhos dos fiéis e da Igreja, significavam uma preparação dos devotos para o desenrolar de uma sensibilidade religiosa mais eficaz em termos de fé. As festas que contavam com tríduos eram consideradas mais importantes, mais preparadas e com maiores chances de "brilhantismo", pois contavam com envolvimento de sacerdotes e de oradores, que podiam ser religiosos ou leigos.

Ao longo das primeiras décadas do $X X$, diversas vezes foi definido a realização de tríduos para a festa de São Miguel. Em 1917, fez-se tríduo e sermão nos dias 27, 28 e 29 de setembro e no domingo, dia 30, missa cantada pela manhã e Te Deum à

\footnotetext{
37 ISMA, Ata, 17 setembro 1928, fl. 138v.

38 ISMA, Ata, 07 setembro 1934, fl. 17.

URBANA, V.4, n05, dez.2012 - Dossiê: Cidades e Sociabilidades - CIEC/UNICAMP
} 
tarde, de modo a aplicar "todo o esplendor possível"39. Essa festa agradou muito aos irmãos, sendo relatado em ata, minuciosamente os principais acontecimentos. 0 Arcebispo D. João Becker e seu secretário participaram; o sermão e as práticas dos tríduos foram feitas pelo Monsenhor Mariano da Rocha, que "muito agradou ao seleto auditório".

As festas nestas primeiras décadas do século XX ganhavam novos significados, se comparadas com as festas do período colonial, pois assumiam os discursos reformadores. Desse modo, as festas limitaram-se ao templo e as relações com o Arcebispado foram fortalecidas de modo que comemorar o dia santo com missa tornava-se oportunidade de divulgação de uma nova espiritualidade. Tratava-se de reforçar e enfatizar a vida sacramental, o culto no templo, a prática da oração, a instrução catequética conforme o modelo romanizado.

A reforma ultramontana do catolicismo também incentivou a devoção mariana. Nas festas de São Miguel percebe-se a importância da participação feminina para enaltecer o culto a Maria, pois: "As ave-marias nos tríduos e na festa foram cantadas pelas senhoras e senhoritas, D. Clemencia Pereira Lopes, Lúcia Jung, Nina Pikergil e nossa irmã Luizinha Barnessitz, as quais ofertamos um registro de São Miguel e Medalha de prata do anjo da guarda, e agradecemos-lhes a gentileza de abrilhantarem nossa festa" ${ }^{\prime 40}$. É sobre esta festa que mais temos relatos sobre o período aqui analisado, como em relação a orquestra, ao sermão, aos gastos e aos convidados: "A orquestra dirigida pelo maestro Tenente Alberto Vokmer e o coro pelos irmãos maristas esteve a merecer louvores por todos que tiveram o prazer de os ouvir".

"O sermão e prática foi pago pela espórtula de cem mil réis ofertado pela Exma. Irmão Juíza D. Amélia de Assumpção Faria. Toda a festa importou em 1:702:400 réis. Tendo expedido convites a diversas irmandades e pessoas altamente colocadas, fizeram-se representar: Irmandade N. S. Mãe de Deus e S.Sacramento, Irmandade Divino Espírito Santo, Irmandade N. S. Conceição do Rosário, Venerável Confraria da Ordem Terceira das Dores e Confraria de N. S. do Rosário, pelo irmão Sampaio, o ilustre Sr. Dr. Montaury, pelo Major Alves da Silva, o Exmo.

\footnotetext{
${ }^{39}$ ISMA, Ata, 11 setembro 1917, fl. 38v.

40 ISMA, Ata, 11 setembro 1917, fl. 38v.

URBANA, V.4, no5, dez.2012 - Dossiê: Cidades e Sociabilidades - CIEC/UNICAMP
} 
General Mesquita pelo Sr. Major Ajudante de Ordens, e o Exmo. Sr. Coronel Affonso Massot, pelo Sr. Tenente Ajudante de Ordens. Ao findar a festa agradecemos a todos a delicadeza de suas presenças".

A troca de gentilezas e a combinação de vários indivíduos participativos nas festas auxiliavam na consolidação do evento, como ocorreu em 1929, quando meninas do Orfanato Nossa Senhora da Piedade e senhoritas cantando Ave-Maria acompanharam o órgão em missa solene ${ }^{41}$.

A importância das festas religiosas também pode ser constatada quando se verifica a preocupação com a confecção de opas. Estas eram as vestimentas típicas de cada irmandade, com cores e estilos próprios ${ }^{42}$. A utilização de opas podia gerar status, prestígio e demonstração simbólica de pertencimento a uma tradicional irmandade da cidade que, historicamente, mantinha viva sua devoção.

No final do século XIX, precisando de opas novas, a Irmandade escreveu para o Rio de Janeiro pedindo para que Ihe remetessem as de seda. Foram encomendadas 30 opas da "melhor qualidade e mais convenientes para a irmandade" ao custo de 35 mil réis cada ${ }^{43}$. Já na década de 1930 , a Irmandade mandaria fazer novas opas para os mesários, encomendando-as no Rio de Janeiro e seguindo o modelo das "antigas opas".

"O vice-provedor (...) lembra ao escrivão, falar com o provedor, a respeito das novas opas que pretende a irmandade mandar fazer, podendo ser o irmão Mario Vieira, portador de uma das antigas opas e também das instruções da forma como devem ser confeccionadas; ainda sobre o referido assunto disse o viceprovedor ter escrito há tempos para o Rio, a uma casa especialista nesses trabalhos, tendo já recebido da dita casa, carta com minuciosos informes, dependendo somente, da

\footnotetext{
${ }^{41}$ ISMA, Ata, 18 setembro 1929, fl. 146.

${ }^{42}$ No dizer da historiadora Mara Nascimento, as opas eram trajes utilizados em determinadas ocasiões e funcionavam como recursos visuais para envolver os assistentes nas cerimônias religiosas ou festivas, constituindo-se como "capas desprovidas de mangas, com aberturas para os braços" (NASCIMENTO, 2006, p. 58).

${ }^{43}$ ISMA, Ata, 02 julho 1895, fl.51.

URBANA, V.4, n5, dez.2012 - Dossiê: Cidades e Sociabilidades - CIEC/UNICAMP
} 
remesse de uma opa, pois a vista desta, poderá a casa ver as dimensões e dar o preço" ${ }^{44}$.

Reunidos em 1937 para pensar a festa, o provedor destacou "ter o monsenhor Balem pedido para que a Irmandade a fizesse um pouco melhor do que nos anos anteriores, devendo a mesma constar de tríduos"45. A mesa foi unanime em aprovar que fossem celebrados tríduos em preparação à festa e o irmão Américo Gay propôs que fosse convidado um orador para os tríduos. Mas diante dessa combinação, o provedor fez "um apelo aos irmãos presentes, pedindo-lhes para que comparecessem aos tríduos e a festa do nosso padroeiro", apelo ao qual diversos irmãos prometeram atender.

O apelo do provedor não surtiu o efeito desejado. No ano seguinte, 1938, ao tratar novamente da previsão de festa, "fez ver aos irmãos que no ano passado foram realizados tríduos em preparação a festa, tendo nessa ocasião solicitado para que comparecesse não só aos tríduos e a festa o maior número possível de irmãos, o que infelizmente não aconteceu, pois aos tríduos compareceram apenas três irmãos" ${ }^{46}$. Desse modo, mais uma vez o provedor aguardava a resolução da mesa quanto a realização ou não novamente dos tríduos e pedia o comparecimento "do maior número de irmãos". Vários irmãos teceram considerações, entre eles, José Antônio Porcello, Albino Dreyer e Jacy do Valle propondo festividades em louvor do padroeiro idênticas as do ano anterior.

Em 1939, a Irmandade avaliava a pouca participação dos irmãos, embora a festa constasse de tríduos, missa festiva, coro e sermão.

"O provedor faz ciente aos irmãos que nos anos anteriores, tem constado as solenidades, em louvor do Padroeiro, de tríduos, missa festiva com acompanhamento do coro da catedral e sermão, sendo este oferecido pela Juíza (...) ainda sobre a festa, diz o provedor, que caso resolva a mesa conjunta efetuar tríduos, solicita aos irmãos, comparecer o maior número possível, para não acontecer como nos anos anteriores, em que compareceu

\footnotetext{
44 ISMA, Ata, 07 setembro 1934, fl. 17.

45 ISMA, Ata, 22 setembro 1937, fl. 03v.

46 ISMA, Ata, 19 setembro 1938, fl. 24v.

URBANA, V.4, no5, dez.2012 - Dossiê: Cidades e Sociabilidades - CIEC/UNICAMP
} 
diminuto número. Usando da palavra diversos irmãos, propuseram para que a festa fosse idêntica a dos anos anteriores, constando de tríduos" ${ }^{47}$.

Por fim, em 1940, a Irmandade desistiu de realizar os tríduos, embora mantivesse a ideia de que a "festa deve ser solene"48. Esta solenidade passava pelos cuidados dedicados ao patrono: missa especialmente dedicada ao arcanjo e às almas sob seu cuidado, música e decoração na igreja, confecção de santinhos para circulação da cultura religiosa e divulgação da Irmandade e do cemitério sob sua invocação.

Aqui é importante fazer um parêntese para destacar que, além de promover a devoção à São Miguel, a Irmandade possuía, de longa data, o encargo de venerar outras três devoções, que são de São Sebastião, São Braz e Sant'Anna. Em 1925, o provedor propunha que "anualmente seja eleita uma juíza para a festa a cada uma dessas imagens encarregando-se de promoverem de acordo com as suas disposições", uma festa nos respectivos dias consagrados às referidas imagens, "o que muito contribuirá para maior realce e devoção das mesmas". A Irmandade passava a se dedicar às outras devoções que estavam sob seus cuidados, destacando as práticas religiosas como importantes para o aumento da veneração.

A distribuição de santinhos durante a festa era um meio de difusão da imagem do Arcanjo e de sua prece e um modo de divulgar o cemitério e a devoção à São Miguel. Esses santinhos também eram um dos elementos da festa e a Irmandade não media esforços para garantir a sua distribuição. No ano de 1943, o provedor ressaltava "que tinha procurado nesta cidade os santinhos a ser distribuídos na festa, mas não os tinha encontrado, e pelo exposto, tinha feito duas encomendas para São Paulo, e no caso de ser atendidas, aproveitaríamos para o próximo ano uma delas" ${ }^{\prime 49}$.

Já de longa data que se distribuíam santinhos nas festas de São Miguel, embora não se possa precisar a data em que este costume iniciou entre os confrades. Em 1934, a Irmandade registrou despesas com a confecção de santinhos ${ }^{50}$ e em 1946, a "habitual distribuição de santinhos a todos os presentes"51.

\footnotetext{
${ }^{47}$ ISMA, Ata, 18 setembro 1939, fl. 39.

${ }^{48}$ ISMA, Ata, 18 setembro 1940, fl. 53.

${ }^{49}$ ISMA, Ata, 10 setembro 1943, fl. 26v.

${ }^{50}$ ISMA, Ata, 07 fevereiro 1934, fl. 04.

51 ISMA, Ata, 15 fevereiro 1946, fl. 37v.

URBANA, V.4, no5, dez.2012 - Dossiê: Cidades e Sociabilidades - CIEC/UNICAMP
} 
No início do século XX, então, as festas foram caracterizadas por celebração de tríduos, reforço na realização de sermões, apresentação de coral, participação de congregações religiosas e distribuição de santinhos, de acordo com os padrões romanos. O culto a São Miguel nas festas estava privado ao espaço da igreja, ao altar consagrado ao padroeiro, local de orações, de rezas, de sermões, de música sacra. Estes eram seus novos significados, suas novas características romanizadas. As festas coloridas, ruidosas nas ruas, acusadas pelas autoridades eclesiásticas de "supersticiosas" pelo excesso de flores e velas não tinha vez na Irmandade São Miguel e Almas de Porto Alegre, pois nem mesmo ocupavam mais o espaço da rua com procissões.

\section{Considerações finais}

Ao longo do período investigado, as primeiras décadas do século $X X$, foi possível perceber que a festa de São Miguel foi pensada pelos irmãos como elementos importantes de manutenção e divulgação da devoção, tanto nos moldes católicos tradicionais quanto na tradição da própria Irmandade de manter seu festejo, sempre que possível, com "pompas". A festa ainda se constituía como um elemento simbólico importante para a confraria de promoção da devoção e das atividades desenvolvidas pela Irmandade através da visibilidade pública adquirida nestes momentos.

Parecia haver um consenso por parte das mesas administrativas de que as festividades eram ocasiões significativas, mesmo que, muitas vezes, conforme as atas, alguns dos próprios irmãos mesários não comparecessem aos tríduos preferindo as missas festivas -, e as juízas nem sempre cumprissem com suas responsabilidades de financiar o sermão. A imagem do Arcanjo provavelmente continuava nas ruas ou no espaço doméstico como protetor do devoto que a ele dirigia súplicas ou confidenciava suas angústias mais íntimas através de orações (GUTTILLA, 2006, p. 91). Mas o culto oficial previa missas no recinto sagrado, seguindo a liturgia romana, local em que os fiéis, de modo contido e disciplinado, prestavam suas homenagens ao Arcanjo.

A preservação dos costumes de celebrar São Miguel e divulgar os nomes da mesa administrativa eleita garantia a continuidade do cuidado em zelar pela instituição. Realizando anualmente eleição de juíza de festa, cuidando as datas festivas, organizando a realização de tríduos, providenciando santinhos para serem distribuídos, anunciando com antecedência na imprensa, confeccionando opas, URBANA, V.4, no5, dez.2012 - Dossiê: Cidades e Sociabilidades - CIEC/UNICAMP 
decorando a igreja e mandando celebrar missas para as almas, a Irmandade consolidava um novo modo de festejar seu patrono. Por isso, não é certo dizer que as festas deixaram de existir, mas apenas que ganharam uma nova dimensão, um novo olhar, um novo enfoque com o catolicismo romanizado. Elas eram feitas em nome da tradição, da devoção, de possíveis outros interesses, como relações de poder, status social e possibilidade de vértice financeira.

\section{Referências bibliográficas}

ABREU, Martha (1999). O Império do Divino. Festas religiosas e cultura popular no Rio de Janeiro, 1830-1900. Rio de Janeiro: Nova Fronteira.

ABREU, Martha e VIANA, Larissa (2009). Festas religiosas, cultura e política no império do Brasil. In GRINBERG, Keila e SALLES, Ricardo. (org.), O Brasil Imperial. Vol. III - 1870-1889, Rio de Janeiro: Civilização Brasileira: 233-270.

AQUINO, Maurício (2012). Modernidade republicana e diocesanização do catolicismo no Brasil: as relações entre Estado e Igreja na Primeira República (1889-1930), Revista Brasileira de História, São Paulo, v. 32, n.63, p. 143-170.

BAREA, Dom José (2004 [1932]). História da Igreja de Nossa Senhora do Rosário. Porto Alegre: EST.

BIASOLI, Vitor (2010). O catolicismo Ultramontano e a Conquista de Santa Maria (1870-1920). Santa Maria: Ed. UFSM.

CAMPOS, Adalgisa (2004). São Miguel, as Almas do Purgatório e as balanças: iconografia e veneração na Época Moderna, Memorandum, 7, p. 102-127.

CATROGA, Fernando (2006). Entre Deuses e Césares. Secularização, laicidade e religião civil. Coimbra: Almedina.

COUTINHO, Emílio Portugal, O hino de ação de graças. Revista Arautos do Evangelho, Disponível em http://revista.arautos.org.br/RAE89-O-hino-de-acao-de-gracas.asp, Acessado em 11.06.2011.

DILLMANN, Mauro (2012). Dia de finados: uma homenagem aos mortos na visita de saudade ao cemitério São Miguel e Almas de Porto Alegre - século XX, Revista Oficina do Historiador, Porto Alegre, Edipucrs, v. 5, n.2, p. 160-179.

ELIADE, Mircea (2010 [1959]). O sagrado e o Profano. A essência das religiões, São Paulo: Editora WMF / Martins Fontes. 
EVARISTO, Carlos (2002). A Real Irmandade de São Miguel da Ala. História e Estatutos - A devoção portuguesa a São Miguel, Anjo de Portugal e da Paz. Fátima, Portugal: Regina Mundi Press.

GUTTILA, Rodolfo Witzig (2006). A casa do santo \& o santo de casa. São Paulo: Landy.

ISAIA, Artur César (1998). Catolicismo e Autoritarismo no Rio Grande do Sul. Porto Alegre: Edipuc.

KARSBURG, Alexandre de Oliveira (2007). Sobre as ruínas da Velha Matriz. Religião e política em tempos de ferrovia. Santa Maria - Rio Grande do Sul, 1880/1900. Santa Maria: Ed. UFSM.

MARIN, Jérri Roberto (2009). A gestão de D. José Maurício da Rocha na Diocese de Corumbá, Revista Brasileira de História das Religiões (Anais do II Encontro Nacional do GT História das Religiões e das Religiosidades), Maringá, v.1, n.3. Disponível em www.dhi.uem.br/gtreligiao/pub.html. Acessado em 22/11/2011.

MAUSS, Marcel (2003 [1950]). Sociologia e antropologia. São Paulo: Cosac Naify.

MENEZES, Renata de Castro. (2009), Celebrando São Besso ou O que Robert Hertz e a Escola Francesa de sociologia têm a nos dizer sobre festas, rituais e simbolismo, Religião e Sociedade. Rio de Janeiro: 29 (1): 179-199.

MICELI, Sérgio (2009). A elite eclesiástica brasileira, 1890-1930. São Paulo: Companhia das Letras.

NASCIMENTO, Mara Regina (2006). Irmandades leigas em Porto Alegre. Práticas funerárias e experiência urbana. Séculos XVIII-XIX. Porto Alegre: Tese de doutorado em História, UFRGS.

PEREIRA, José Carlos (2005). Devoções marginais: intefaces do imaginário religioso. Porto Alegre: Zouk.

SANTIROCCHI, Ítalo Domingos (2010). Uma questão de revisão de conceitos: romanização, Ultramontanismo, Reforma. Temporalidades, Revista Discente do Programa de Pós-graduação em História, UFMG, vol.2, n.2, p. 24-33.

SOUZA, João Carlos (2008). Sertão Cosmopolita. Tensões da modernidade de Corumbá. 1872-1918. São Paulo: Alameda.

TAVARES, Mauro Dillmann (2008). Irmandades, Igreja e Devoção no sul do Império do Brasil. São Leopoldo: Oikos/Unisinos.

VOVELLE, Michel (1991). Ideologias e mentalidades. São Paulo: Brasiliense. 